\title{
ISLAMIC COLLEGES IN CENTRAL SUMATRA IN THE 1930S-1950S: THE BEGINNING EFFORTS OF BRINGING BETWEEN THE ISLAMIC SCIENCE AND THE WESTERN SCIENCE AT LOCAL LEVEL
}

\author{
Dedi Arsa \\ Institut Agama Islam Negeri (LAIN) Bukittinggi \\ e-mail: deddyarsya1987@gmail.com
}

\begin{tabular}{|l|l|l|}
\hline Submission: 13 Augustus 2019 & Revised: 2 December 2019 & Published: 10 December 2019 \\
\hline
\end{tabular}

\begin{abstract}
This article discusses the discourse of Islamic Colleges in Indonesia and its realization at the local level with the establishment of Islamic Colleges in Central Sumatra, throughout the late 1930s to the 1950s.During that period, the initial discourse on Islamic Colleges in the national level went on sardonically, especially over bridging the Islamic sciences and general sciences (Western); the lingua francareferred to (Malay, Arabic, Dutch, or English); who should engender the Islamic Colleges; and who should manage them. This discourse at the national level involved prominent scholars like Satiman and Natsir, then Hatta in the following period. Their ideas were then realized in the form of the establishment of Colleges at the local level (regional), one of which was in Central Sumatra, during that period, there had been two Islamic Colleges: Sekolah Islam Tinggi (SIT) P.G.A.I in Padang in the late of colonial period and Darul Hikmah University (UDH) in Bukittinggi at the beginning of independence. Even though both of them were short-lived, they had become a prototype for Islamic Colleges in the following period as an effort to reconcile Islamic sciences and Western sciences, which is now popular as a science integration movement.
\end{abstract}

Keywords: Islamic colleges, Science integration, Central Sumatra.

\section{Abstrak}

Artikel ini membahas diskursus sekolah tinggi Islam di Indonesia dan realisasinya di tingkal lokal dengan didirikannya sekolah-sekolah tinggi Islam di Sumatra Tengah sepanjang 1930an akhir bingga 1950an. Selama kurun itu, diskursus awal tentang pendidikan tinggi Islam di nasional berlangsung sengit, terutama bersoal menjembatani ilmu-ilmu keislaman dan umum (kebaratan); bahasa pengantar yang diacu (Melayu, Arab, Belanda, atau Inggris); siapa yang harus melabirkan sekolah tinggi Islam; dan siapa pula yang harus mengelolanya. Diskursus ini di tingkat nasional melibatkan para cendikiawan terkemuka serupa Satiman dan Natsir, lalu Hatta dan lain-lain di masa setelabnya. Gagasan-gagasan mereka kemudian direalisasikan dalam bentuk pendirian-pendirian perguruan tinggi di tingkat lokal (daerah), salab satunya di Sumatra Tengah, di mana selama kurun itu telah berdiri berturut-turut dua sekolah tinggi Islam: Sekolah Islam Tinggi (SIT) P.G.A.I di Padang pada masa akhir kolonial dan Universitas Darul Hikmah (UDH) di Bukittinggi pada awal kemerdekaan. Sekalipun keduanya berumur singkat, tetapi telab menjadi role models bagi sekolah tinggi Islam yang ada di periode setelahnya sebagai upaya yang sama untuk. mendamaikan antara ilmu-ilmu keislaman dan kebaratan, yang sekarang populer sebagai gerakan integrasi ilmu.

Kata Kunci: Sekolah tinggi Islam, Integrasi ilmu, Sumatra Tengah

\section{Background}

The growth of Islamic Colleges in Indonesia, and in the Southeast Asian-Muslim (Malay) region in general, was full of dynamics and diverse. Anthony Welch, regarding this, called this region as "Represents a dynamic and diverse arena of Islamic higher education" ${ }^{1}$. This dynamic development, for the case of Indonesia, began with the earliest discourse on Islamic Colleges that went on sardonically, since the late 1930s involving prominent Islamic thinkers of their time such as Satiman and M. Natsir. This war of ideas

1 Anthony Welch, 'Seek Knowledge throughout the World? Mobility in Islamic Higher Education', Research in Comparative and International Education, 7.1 (2012), $70-80$ <https://doi.org/10.2304/rcie.2012.7.1.70>. 
led to the the establishment of Islamic Colleges in several areas, in Jakarta, Solo, Yogyakarta, and in Central Sumatra.

Specifically in Central Sumatra, the emergence of Islamic Colleges in this earliest period represented how compromising the face of Islam in the Malay world. The presence of Islamic Colleges could synergize the frictions of Islam (Kaum Muda [young people] and Kaum Tua [the elderly]_or traditional groups and reformers-who were sardonically 'in conflict') in one shared forum for a moment. This was never done before because they had their own educational institution. In addition, the presence of Islamic Colleges was also an effort to bridge between the religious/ Islamic sciences and Western sciences-now popular as science integration movement.

Many studies of Islamic Colleges history in Malay or Indonesia (both traditional and modern) have been carried out. Though, the reviewers almost ignored the history or the growth of Islamic Colleges at the local level in the earliest period. So far, the available studies about the growth of Islamic Colleges were done by Fuad Jabali \& Jamhari discussing the relevance of IAIN and Islamic modernization ${ }^{2}$; Hiroko Kinoshita discussing the role and the intellectual track record of $\mathrm{Al}$ Azhar alumni in Islamic Collegesin Indonesian contemporary ${ }^{3}$. Today's issues surrounding the world of Islamic Colleges were analyzed by

${ }^{2}$ Fuad Jabali and Jamhari, IAIN \& Modernisasi Islam di Indonesia (Jakarta: Logos Wacana Ilmu, 2003), p. 21.

${ }^{3}$ Hiroko Kinoshita, 'Islamic Higher Education in Contemporary Indonesia: Through the Islamic Intellectuals of Al-Azharite Alumni', in Kyoto Working Paper on Area Studies, No. 79 Kyoto University, 2009<https:// repository.kulib.kyotou.ac.jp/dspace/bitstream/2433/155748/1/ssh_081.pdf $>$. $\{$ accessed 7 December 2019$\}$.
Johan Hendrik Meuleman ${ }^{4}$, Zamakhsyari Dhofier $^{5}$, and Azyumardi Azra ${ }^{6}$.

Another study that discussed deeper about the growth of Islamic Colleges in Indonesia was carried out by R. Lukens-Bull, but he still ignored the dynamics occurred at the local level in the early period ${ }^{7}$. Likewise, the study done by Hasbi Indra, illustrated Islamic Colleges with its long history. According to him, the Islamic Colleges has existed since the Indonesian Independence Era, which clearly has ignored the growth of Islamic Colleges in Central Sumatra that had established the Islamic Colleges since colonial era ${ }^{8}$.

While regarding the efforts of scientific synergy, especially related to the relations of science and religion (general science and religious science), in Islamic Colleges, was discussed by H. Akh. Minhaji who described the changes in the institutions of Indonesian Islamic Colleges which were followed by changes in academic vision ${ }^{9}$. Marwan Salahuddin also sought to discuss the dichotomy between religion science and general science that occurred at Islamic Colleges, and to introduce Islamic Collegesin Indonesia as a model of college that integrated

Johan Hendrik Meuleman, 'IAIN di Persimpangan Jalan', in Problem \& Prospek LAIN: Antologi Pendidikan Tinggi Islam (Jakarta: Departemen Agama RI, 2002), p. 23.

5 Zamakhsyari Dhofier, 'Refleksi atas Visi dan Misi IAIN', in Problem \& Prospek LAIN: Antologi Pendidikan Tinggi Islam (Jakarta: Departemen Agama RI, 2002), p. 32.

6 Azyumardi Azra, 'IAIN di Tengah Paradigma Baru Perguruan Tinggi', in Problem \& Prospek IAIN: Antologi Pendidikan Tinggi Islam (Jakarta: Departemen Agama RI, 2003), p. 6.

${ }^{7}$ Ronald A. Lukens-Bull, Islamic Higher Education in Indonesia: Continuity and Conflict (New York: Pargrave Macmillan, 2013), p. 32 <https://doi.org/10.1057/9781137313416>.

8 Hasbi Indra, 'Pendidikan Tinggi Islam dan Peradaban Indonesia', Al-Tabrir: Jurnal Pemikiran Islam, 16.1 (2016), 109 <https://doi.org/10.21154/altahrir.v16i1.317>

${ }^{9}$ Akh. Minhaji, 'Masa Depan Perguruan Tinggi Islam di Indonesia; Perspektif Sejarah-Sosial', Tadris Jurnal Pendidikan Islam Jurusan Tarbiyah STAIN Pamekasan, 2.2 (2007), 154. 
religious science into general science ${ }^{10}$. Afiful Ikhwan enriched it by explaining theoretical conceptual efforts for the scientific integration movement ${ }^{11}$.

From the above description, it can be concluded that the research on the history of Islamic Colleges at the local level (Central Sumatra) at an earlier time, namely in the 1930s-1950s has never been done seriously and deeply.

For this reason, this article elaborates on how the earliest discourse on Islamic Colleges at the level of Indonesian Muslim thinkers took place and how Central Sumatra responded to this discourse related to how this region realized the establishment of Islamic Colleges in the 1930s-1950s - when the discourse itself was still ongoing - in an effort to synergize the Islamic and Western elements that were competing vigorously in that region.

This article is a historical article with a historical education approach, which observesat the growth of educational institutions over a certain period of time. Therefore, the way it works uses the workings of compilation which are generally known in modern history compilation methods, which include four stages: heuristics in the form of material/source collection, source criticism in the form of internal-external criticism, interpretation, and explanation in the form of historiography ${ }^{12}$.

10 Marwan Salahuddin, 'Model Pengembangan Pendidikan Tinggi Islam di Indonesia', Ulumuna, 18.1 (2017),

<https://doi.org/10.20414/ujis.v18i1.155>.

11 Afiful Ikhwan, 'Perguruan Tinggi Islam dan Integrasi Keilmuan Islam : Sebuah Realitas Menghadapi Tantangan Masa Depan', Juran At-Tajdid, 5.2 (2016), 159-87.

12 Ralph Schroeder and Christopher Lloyd, The Structures of History (UK: Blackwell Oxford, 1995), p.1 <https://doi.org/10.2307/3034263>; Kuntowijoyo, Metodologi Sejarah, Edisi Kedua, Tiara Wacana Yogya (Yogyakarta, 2003), p.32. ; Gilbert J. Garaghan, A. Guide to Historical Method (New York: Fordham University Press, 1984), p. 124.
From this article it can be identified that the early discourse on Islamic Colleges involved two major thinkers of Muslim scholars, Satiman and M. Natsir, who werealso followed later by M. Hatta. What they discussed was about the efforts of bridging between Islamic science and Western science (westerch) and the intervention of the state in the matters of Islam (religious and state relations). This discourse, directly or indirectly, stimulated the establishment of Islamic Colleges in Central Sumatra throughout the 1930s-1950s, which seemed to attempt to synergize two opposing praxis, between modernist praxis and Muslim traditionalist praxis, and to integrate the scientific basis that was often disputed betweenIslamicsciences and Western sciences.

\section{The Efforts to Integrate Science in the Late of Colonial Era}

Ideas about the establishment of Islamicstyle Colleges had begun to be expressed by some Islamic nationalists at the end of Dutch reign in Indonesia. In May 1938, Pandji Islam reported that in Jakarta there had been a conference of the high school founding body to design the establishment of Islamic Colleges in three cities. In Jakarta, Muhammadiyah Middle School (A.M.S) would be developed into an Islamic College, but "westernized". While in Solo, Islamic College would also be established to educate mubalighin (Islamic preachers) who had sufficient general knowledge. In the same year, in Surabaya, Dr. Sutomo was planning to establish a college that would "accept people from pesantren (Islamic Boarding School)" ${ }^{13}$. While Dr. Satiman Wirjosandjoyo in Mauleman at the same time had established Luhur Islamic Boarding School Foundation, an Islamic boarding school which was expected to

13 Muhammad Natsir, Capita Selecta (Bandung: Penerbit Bulan Bintang, 1973), p. 90. 
become the center of Islamic Colleges in Indonesia ${ }^{14}$.

Dr. Satiman was one of the important figures who started thediscourse on Islamic Colleges. The idea of an Islamic Colleges was openly present when he issued an article in 1938 about the importance of establishing an Islamic College in the Pedoman Masyarakat. In that article, Satiman conveyed several main ideas. According to Satiman, the Islamic community was far behind in the development of higher education compared to non-Muslim community. Dutch Colleges had already existed and gained wide space among the educated Dutch East Indies. From these colleges, were born Western-educated nationalist figures who later became Indonesian new elites. While Muslims were just a few steps behind to have their own college $\mathrm{e}^{15}$.

The efforts to bridge between the Islamic lessons and general lessons (western) became an important topic that was polemic in this early period. Satiman, for example, wanted that Islamic Colleges would later be able to spur the backwardness of Muslim education by trying to adoptgeneral science lessons. Muslims would still be left behind if they did not do it. Satiman wrote further that the Muslims who built schools with pesantren system were left behind, not only at the college levelbut also at the elementary to high school level, compared to Dutch schools and other schools that were built in the Dutch system. The schools based on pesantren system were left so far behind and suffered a sad fate of not being able to respond to the needs of a growing community. Satiman wrote:

14 Meuleman.

15 Satiman Wirjosandjoyo, 'Pendirian Sekolah Tinggi Islam', Pedoman Masjarakat, 6.19 (1938), 1-12.; Jabali and Jamhari.; Hardianti, 'Pemikiran Politik Islam Soekiman Wirjosandjojo (1916-1960 M)' (unpublish bachelor thesis, UIN Sunan Ampel, 2018), p. 20.
"When Indonesian people were still sleeping, religious education in the pesantren met the public needs, but after they woke up and felt the result of studying from various schools, from elementary schools to high schools, people felt dissatisfied with the result of studying at pesantren ... People now see the lack of our religious guides, which cannot be compared to Christian guides who can mostly be educated in College. It is not surprising if the influence of Islam is getting smaller and smaller and the colony is getting narrower. Islamic boarding school and madrasah education can indeed produce people who believe and behave well, but are indifferent to the development of the world "16.

According to Satiman, non-Muslim societies were advanced because they adopted the Western-style education system. So far, people who were graduated from Western schools had been active in the national movement, while those who were educated at Pesantren were left far behind. That's the reason why Satiman considered that Islamic Colleges could be used as a tool to catch up, and put the Islamic community in thegroup of educated people who were jointly involved against the Dutch ${ }^{17}$.

In addition, Satiman also inferred that it was necessary to connect the Islamic education system to the International world. In order to improve the quality through Colleges, Indonesian Islamic society must be closely linked to two worlds: the world in which they stood (national) and the outside world (international). Even though, in the same article Satiman mentioned that in Islamic education, local elements were also important to be noticed. Satiman included Hindu lessons, because according to him, "this religion became a service of Indonesian culture (Java)", in addition to Javanese mysticism and the Islamic saints' books. Meanwhile, to build their relationship with the

${ }^{16}$ Wirjosandjoyo.; Jabali and Jamhari.
${ }^{17}$ Wirjosandjoyo.; Jabali and Jamhari. 
outside world, "students in Islamic Colleges must study English, the history of the philosophies of each religion, as well as guidance in the science of philosophy into the curriculum". Satiman firmly convinced that if the conditions proposed were fulfilled, Islamic Colleges would multiply and "would live forever". This was because it was supported by a strong mass, the largest Muslim community in Indonesia, and these colleges werenot ruled by unknown people, but by "people who had intellect the same as Western people $" 18$.

Responses to Satiman's ideas emerged from one of Muslim intellectual circles who was as influential as him. Natsir, in the same year, wrote an incisive criticism for Satiman's ideas. Natsir, a young Muslim scholar who began to be counted on since he began to write a lot of Islamic and national issues at that time, on some sides agreed with Satiman's ideas, but on some other sides strongly rejected his ideas. In June 1938, Natsir wrote an article titled "Sekolah Tinggi Islam (Islamic Colleges)" in the same magazine. Natsir, in his article, argued that it was better to emphasize the importance of Islamic Colleges producing intellectual groups that had strong Islamic and cultural knowledge bases rather than adopting a Western-style education pattern as proposed by Satiman. Natsir wrote that each college, as was Satiman's idea, prioritized general knowledge. But that was not all. "What is also important is the maturity of the brain (maturiteit) or sufficient spiritual supplies to think along the lines of science,"19.

Opposing on Satiman who wanted English as the main language needed to be learned in Islamic Colleges, and considered English as the lingua franca, Natsir preferred Arabic as the lingua franca used in Islamic

${ }^{18}$ Wirjosandjoyo.; Jabali and Jamhari.

19 Muhammad Natsir, 'Sekolah Tinggi Islam', Pedoman Masjarakat, 6.21 (1938), 1-12. ;Natsir, Capita Selecta.
Colleges. Nasir argued that Arabic actually had become part of Muslim community in Indonesia and been familiar to them. Natsir wrote:

"The basic lessons for the Islamic College are the knowledge which has deep-rooted about Islamic sciences using Arabic language and it's the treasury key ... when the Western-language intelligence is the only one being prioritized in designing the plan for Islamic College, it means we close our eyes to the most influencing intelligence that has been part of our society." 20

Natsir ${ }^{21}$, like Satiman, assumed that Muslims had to have their own Colleges. "Indonesian Muslims need higher education," Natsir wrote. The graduates of Islamic high schools were very abundant, but Islamic Collegesas the continuation of the secondary education did not exist. For this reason, according to Natsir, Islamic Colleges must accommodate the hundreds of Islamic high school graduates. Furthermore, in the process, according to Natsir, ${ }^{22}$ an Islamic College graduate cannot be seated together with an H.B.S. graduate (Public High School) to learn the lesson.

Although Satiman and Natsir had striking different opinions about Islamic Colleges, both of them agreed on one thing: Islamic Collegesshould be born from the womb of the Muslim community. "The initiative of establishing Hoogeschool Islam (Islamic College) has to come out of Muslim community," wrote Satiman in 1938. In the same year, Natsir agreed: "Islamic Collegesthat aredirectly related to the efforts of the people will stand by firmly because it roots in one foundation of strength and determination of the people which has been proven."

Related to the intention of establishing the Islamic Colleges, Natsir said:

\footnotetext{
${ }^{20}$ Natsir, 'Sekolah Tinggi; Natsir, Capita Selecta.

${ }^{21}$ Natsir, 'Sekolah Tinggi; Natsir, Capita Selecta.

${ }^{22}$ Natsir, 'Sekolah Tinggi; Natsir, Capita Selecta
} 
“... It is not just about answering people's question'whether Muslims in Indonesia have already had anIslamic College'.Moreover, it's not only about teaching, but also about streamlining the people's strengths and efforts in education, and becomingthe center of leadership based on the initiative of our own people." 23

The explanation above has revealed how the discourses on Islamic Colleges grew from the late 1930s to the early 1940s. However, it is not clear yet how exactly the ideas of Islamic Colleges spread in Java, through the polemics in the newspaper responded by people in Sumatra. Similarly, there is no sufficient evidence whether the people in Sumatrawere involved in the debate on Islamic Colleges that Satiman and Natsir started in 1938 in the Pedoman Masjarakat magazine. Did local Sumatran leaders have their own thoughts on, for example, their dreams of an Islamic College?

However, it can be assumed that Natsir, who came from that area, had engaged in conversations with the Muslim leaders there; even if that did not happen, Muslim leaders in that area had come into contact with the ideas of the establishment of Islamic College through newspaper reports whose readership scale had expanded in that period.

By 1940, less than two years since Satiman and Natsir were involved in a polemic about the ideas of Islamic College, the local Muslim community in Sumatra had begun to feel and realize that Islamic College had to be established in their area. The driving factors of the emergence of the desire to have the Islamic College in Sumatra, especially in the Central Sumatra, were varied. One of the driving factors was the abundant graduates of Islamic High School who had the intention to continue their study to the higher level while

\footnotetext{
${ }^{23}$ Natsir, 'Sekolah Tinggi; Natsir, Capita Selecta.
}

in this area there was no Islamic college that was able to accommodate their desire ${ }^{24}$.

On the other hand, the passion for establishing college in the context of that era was also blazing in Indonesia, or at least in Java. In 1937, for example, when Muhammadiyah held its quarter-century congress in Jakarta, this Muslim organization which had many followers in Sumatra had decided to establish an economic College in the near future ${ }^{25}$. This has indirectly increased the enthusiasm of Sumatran people who were the majority of Muhammadiyah people and encouraged the local Islamic leaders to also think about college. In addition, in 1938, Dr. Satiman in Lukens also succeeded in realizing his idea of an Islamic college by establishing Luhur Pesantern in Solo that was famous at that time ${ }^{26}$. It was believed that some of those developments were considered to stimulate the Islamic Teachers Association (Persatuan Guru Agama Islam/P.G.A.I) in Sumatra gathered in 1940 to initiate the establishment of the Islamic College (Sekolah Islam Tinggi/SIT) P.G.A.I.

Sekolah Islam Tinggi P.G.A.I became the first Islamic Tertiary Institution in Sumatra. Built in Padang, an important city on the west coast of Sumatra, this Islamic College had three majors: Arabic Language, Religious Sciences, and Islamic Zending27. This Islamic College had two faculties: Law or Sharia, and Arabic and Education 28. Using one of the

${ }^{24}$ Tim Kementerian Penerangan, Sumatera Tengah (Jakarta: Penerbit Kementerian Penerangan, 1953), p. 625-6.

${ }_{25}$ Anthony Welch, 'Seek Knowledge throughout the World? Mobility in Islamic Higher Education', Research in Comparative and International Education, 7. 1 (2012), $70-80$

<https://doi.org/10.2304/rcie.2012.7.1.70>.

${ }^{26}$ Lukens-Bull.

${ }^{27}$ Mahmud Yunus, Sedjarah Islam Di Minangkabau: Keringkasan (Jakarta: Al-Hidajah, 1971), p. 68-69.; Tim Kementerian Penerangan.

28 Mahmud Yunus, Sedjarah Pendidikan Islam di Indonesia (Jakarta: Hidakarya Agung, 1996), 117-121 $<$ https:// scholar.google.com/scholar?hl=en\&q=pendi 
classes in Normal Islam Padang, the first SIT P.G.A.I students numbered approximately 20 people who were graduated from Normal Islam Padang, Islamic College, Kulliyatul Muballighin ${ }^{29}$.

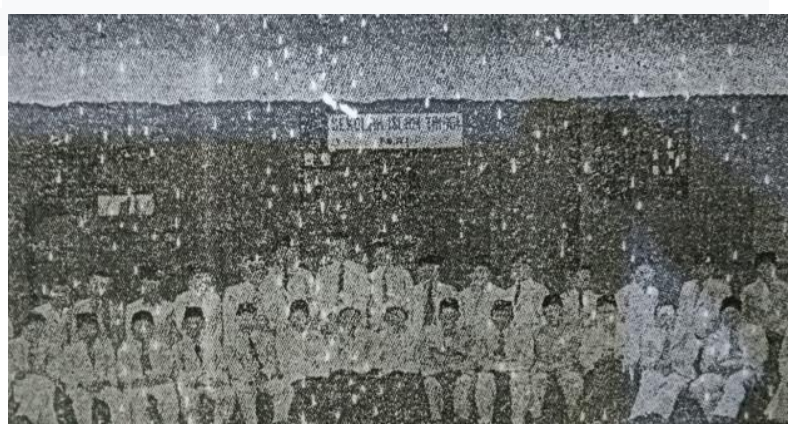

Picture 1. The opening of Sekolah Islam Tinggi's first lecture on December 9, 1940 (Source: Mahmud Yunus, Sedjarah Islam di Minangkabau, p. 70)

The director of SIT P.G.A.I was Mahmud Yunus who also became the lecturer. The other lecturers, besides Mahmud Yunus, were young scholars who were already quite well known in their time: Nasharuddin Thaha, Muchtar Yahya, and Husain Yahya, who were graduated from Darul Ulum, Egypt ${ }^{30}$. Egyptian graduates did indeed dominate Muslim scholars and educators at this time and the following period ${ }^{31}$. Some other lecturers were local graduates and scholars from among the elderly, including Abu Bakar Djaar, S.M. Latief, Saleh Djaafar, and Shaykh

dikan+islam\&btnG $=\&$ as_sdt $=1 \% 2 C 5 \&$ as_sdtp $=\# 3>$.; Yunus, Sedjarah Islam.

${ }^{29}$ Yunus, Sedjarah Pendidikan.; Yunus, Sedjarab Islam; Muhammad Dalir Djamin, 'Riwajat Ringkas Prof. H. Mahmud Junus', in Brosur Menyambut Dies Natalis Ke1 LAIN Al Djami'ab Imam Bondjol Sumatra Barat (Padang: Seksi Publikasi/Dokumentasi Panitia Dies Natalis ke-1 IAIN Al Djami’ah Imam Bondjol, 1967), p. 4.

${ }^{30}$ Yunus, Sedjarah Pendidikan. ; Yunus, Sedjarah Islam; Tim Kementerian Penerangan.

${ }^{31}$ R. Michael Feener, 'Indonesian Movements for the Creation of a "National Madhhab", Islamic Law and $\begin{array}{llll}\text { Society, } & 9.1 & \text { (2002), } & \text { 83-115 }\end{array}$ <https://doi.org/10.1163/156851902753649298>.; Mona Abaza, Islamic Education: Perceptions and Exchanges: Indonesian Students in Cairo (Paris: EHESS, 1994), p. 20.; William R Roff, 'Indonesian and Malay Students in Cairo in the 1920's', Indonesia, 1970, 73-87
Ibrahim Musa Parabek ${ }^{32}$. It is interesting to note how modernists were accommodated in a shared forum at this college which had never existed before; previously the elderly and young people taught at their own institutions.

This school did not survive more than two years, because in March 1942 this Islamic college was disbanded as the Japanese fleet landed in Padang ${ }^{33}$. However, the existence of this Islamic College has indicated to us how the region's rapid response to the discourse about Islamic Colleges that had developed in Indonesia in the same period.

\section{The Efforts of The Integration of Science} at the Beginning of Independence

In Java, the discourse of Islamic Colleges was vanished during the reign of Japan. It was after the independence, the same ideas began to appear again as they had emerged at the end of the colonial period (by Satiman and Natsir). In 1945, just after Indonesian independence was announced, Mohammad Hatta actively relaunched the ideas about the importance of Islamic Colleges for Muslims. Hatta echoed the ideas about Islamic colleges louder before the Indonesian independence. Hatta was motivated by the aspiration to integrate the "mosque education" system and general education. In Hatta's viewpoint, the first education system had "strengths in teaching religious values", but was weak in the development of general knowledge. Meanwhile, public schools were the opposite, concentrating on developing the ability of ratios and general sciences, but ignoring religious education, even though religion plays an important role in humanizing humans. Islamic Colleges, said Hatta, were expected to link the gap. Islamic College were expected to produce the Muslim scholars who not only

${ }^{32}$ Yunus, Sedjarab Pendidikan. ; Yunus, Sedjarah Islam ; Tim Kementerian Penerangan.

33 Yunus, Sedjarah Pendidikan; Yunus, Sedjarah Islam. 
understood about religion but also understood about the changes in their own society ${ }^{34}$.

In Hatta period, the idea of an Islamic College gained new emphasis. In July 1945, Hatta wrote a memorandum emphasizing that in the Indonesian context, Islam was an important factor that was absolutely taken into account in the development of society. "For the people of Indonesia, which are more or less ninety percent embracing Islam, perfecting religious education is one of the matters ... to strengthen the position of the community," Hatta wrote. "To accomplish the Islamic education, it is necessary to establish an Islamic College," Hatta wrote again ${ }^{35 .}$

Hatta wanted Islamic colleges to be able to portray themselves as a bridge between Islamic education on one side and Westernstyle education or traditional and modern-style education on the other side. "Dogmas alone are only able to embed beliefs, maybe even beliefs that come with narrow understandings. But philosophy expands the nature and feelings and teaches to analyze using deep view points and feelings," said Hatta. As long as Islam was studied and treated as a mere doctrine, religion would cease to be limited to beliefs that may not necessarily be applied in daily life that was constantly changing. Hatta considered, the best way was to apply education through philosophical, historical and sociological approaches.

Meanwhile, regarding the law, Hatta considered that the law must be seen empirically. How a law appears in a society at an important time to be seen. For this reason, a historical study of the law was inevitable. "If not with its history, religious law can be memorized, but it cannot really be understood about what it is," Hatta wrote. In this context too, an understanding of the society in which the law was formulated and applied from time to time was absolutely necessary. On this

34 Jabali and Jamhari.

35 Jabali and Jamhari. basis, according to Hatta, sociology must also be an important part of the curriculum in Islamic Colleges. In Dhofier, Hatta's full writing:

"Islamic pious scholars, who understand religious law but do not understand the community, are unable to provide leadership to the community ... Islamic teachings that want to give leadership to the community must rely on sociological knowledge" ${ }^{\prime 36}$.

In Sumatra, Mohammad Hatta together with Muhammad Yamin (who became the Minister of Education in the early 1950s), actively encouraged local leaders to establish college. Hatta in Samry, for example, argued that there must be one university in each province in Sumatra, such as in North Sumatra, in Central Sumatra and in South Sumatra $^{37}$. On one occasion of the tour to Central Sumatra, Hatta said, "There are places that only have elementary schools and S.M.P (Junior High School). After that, where will the students go? Continuing their study to S.M.A (Senior High School) and universities in Java were not financed by their parents." Seeing this reality, Hatta suggested, "It would be nice if the smartest students among them could continue their school at their own place or at least in Central Sumatra Province" ${ }^{138}$.

Not only encouraging the existence of College, but Hatta on the same occasion also encouraged the presence of Islamic College. Hatta said that Central Sumatra, which was a granary of the Islamic pious scholars, with an abundance of Islamic intellectuals, must also have its own college that was able to accommodate the students from this area ${ }^{39}$.

Not long after Hatta's call, in the same range of years, Iljas Jacoeb (read: Ilyas Yakub),

${ }^{36}$ Dhofier.

37 Wannofri Samry and Yudhi Andoni, Demi Kejayaan Bangsa, Sejarah 50 Tabun Universitas Andalas (Padang: Unand Press, 2006), p. 14.

${ }^{38}$ Samry and Andoni.

39 Samry and Andoni. 
an influential Muslim intellectual in the area, initiated the formation of the first Islamic College in Central Sumatra in the period of Indonesian independence. Whether there was a connection between the establishment of this Islamic College and Hatta's call or not, there was not enough information to explain this. Though, on March 16, 1953, in Bukittinggi was established Darul Hikmah College which was engaged in Islamic education. Nasruddin Thaha played the role as the chairman of the committee for the establishment of the college ${ }^{40}$.

Besides Ilyas Yakub, there were several important regional figures who were involved in realizing the dream of the Muslim community in Central Sumatra to have an Islamic College: Dt. Palimo Kayo, A. Malik Ahmad, Buchari Tamam, Dahlan Ibrahim, Rangkayo Ratnasari, and several other figures. The curator was the Governor of Central Sumatra at the time, Roeslan Muljoharjo, together with Ilyas Jakub, Diyari Karim, S.J. St. Mangkuto. The first chancellor was a moderate charismatic Islamic pious scholar from the highlands, Shaykh Ibrahim Musa Parabek $^{41}$.

Darul Hikmah College was born from the desire of Islamic figures in Central Sumatra to accommodate the increasing number of the secondary Islamic high school graduates. In its articles of association, it was stated that Darul Hikmah aimed to educate Islamic national cadres and to accommodate secondary Islamic high school students who annually issue around 300 students ${ }^{42}$. Graduates were expected to "become Mujahideen who would adjust and implement Islamic laws among society and the State" ${ }^{13}$.

The establishment of the Islamic College it self had been approved and fully recommended by the Islamic pious scholars in Central Sumatra through a large meeting one day before the 7 th Indonesian Independence Day was commemorated. On August 16, 1952, the Central Sumatran Islamic pious scholars met in Bukittinggi, which resulted in a decision that the Muslims of Central Sumatra had to have an Islamic College again. This decision further mandated Nashroedin Thaha to form an Islamic College Committee ${ }^{44}$.

After the Darul Hikmah College was established on March 16, 1953, one month later, on April 20, 1953 the Darul Hikmah Foundation was formed as its manager. 45 This foundation, in its articles of association, said that it would try to build and organize the Darul Hikmah Islamic College and fight for the future of this Islamic College "to be able to live together in College Education Center".46 In addition, the foundation would also build a library "which was complete with various sciences, civilizations and philosophies, especially those related to Islam". The library would later be named "Darul Hikmah Library". This foundation encouraged and supported the efforts of ijtihad and investigations in matters of Shari'a, law, culture, especially those related to Islam ${ }^{47}$.

The spirit of Islamic teaching that combined the features of religious knowledge and general knowledge was alsonoticed in its articles of association, where it was stated that the Darul Islam College existed to "deepen and broaden Islamic law and its Shari'a", to equip the students with "general knowledge that had strong relation with Islamic knowledge ". In addition, Darul Hikmah was also present to produce the people who were competent to become the government staffs which were lacking at that time. In its articles of association, it was stated that Darul Hikmah

\footnotetext{
${ }^{44}$ Tim Kementerian Penerangan.

45 Tim Kementerian Penerangan.

${ }^{46}$ Tim Kementerian Penerangan.

${ }^{47}$ Tim Kementerian Penerangan.
} 
would go deep into "the religious knowledge and its wisdom in order to prepare the people who were capable of and beneficial for the struggle to create safety, prosperity, and civilization in Indonesian society and the world in full accordance with Islamic teachings" 48 .

This Islamic College had several levels: Candidate I (C I); Candidate II (C II); Doctoral I (D I); Doctoral II (D II). This Islamic College had three faculties: Law and Sharia, Ushuluddin and Da'wah, and Arabic and Education. While the lecturers that were recorded, were prominent educators and Islamic pious scholars of that era such as Shaykh Ibrahim Musa teaching Ushul; Shaykh Abbas Abdullah teaching Tafsir (Alqu'ran Interpretation); Shaykh Sulaiman Ar-Rasuli teaching Fiqih; L Mudo Hamid Hakim teaching the Hadith; Bustami Abdul Gani teaching Arabic; Nashroeddin Thaha teaching Islamic History and Islamic Law History at the same time; Mr. Harun Al-Rasjid teaching Introduction to Law; A. Sani teaching Sociology; Adam Saleh teaching Indonesian; A. Hamid teaching English; and A. R. Sutan Mansur teaching Tawheed Science 49. Meanwhile, some other lecturers were adjunct lecturers because they did not currently reside in West Sumatra, for example, in Djamin Mahmud Yunus who was then serving in Jakarta. He was listed as a lecturer at this College in $1955^{50}$.

Nevertheless, this Islamic College (as its predecessor-the short lived Sekolah Islam Tinggi [SIT]) was also dissolved before it could realize its ideals any further. Only a few months after an uprising in Central Sumatra erupted against the Soekarno regime, this Islamic College, "was forced to close down," according to the Sumatra Tengah report, the mouthpiece of the Ministry of Information at

\footnotetext{
${ }^{48}$ Tim Kementerian Penerangan.

${ }^{49}$ Tim Kementerian Penerangan.

${ }^{50}$ Djamin.
}

that time ${ }^{51}$. There were not enough sources available to explain everything about how and why the school was closed. For example, were some of its lecturers involved in the rebellion or not? It was discovered that after "dissolving", the Darul Hikmah Islamic College almost never rose again.

\section{Finding the Right Integration Model}

In 1958, a rebellion erupted in Central Sumatra, widely known as the PRRI Rebellion ${ }^{52}$. During the riots, the education process was vacuumin this area. The vacuum continued even after the war was over. The regional elites, who suffered defeat due to the exhausting war, had almost lost the initiative to restart what their predecessors had initiated in the previous period-to rebuild Islamic Colleges in the area. Many of most important Muslim pious educators and scholars in this area were involved in the uprising, and after the uprising they almost "had no right" to speak out ${ }^{53}$.

The initiative to re-establish an Islamic College actually came from the "winner of the war" and the elites who wandered about and were deemed clean of "historical sins" against the legitimate government. They began to be summoned or called up to go back home to build their hometown that had been ravaged because of the war ${ }^{54}$. A book that seems to have been compiled for memorabilia purposes recorded that the Commander of the Kodim 17 August, the military command most credited with "bringing the rebels to sea", was the main initiator to re-establish Islamic Educational Institutions after the war. In a book compiled by Yulizal Yunus et al, the name of Brigadier General Surjo Soempono

51 Tim Kementerian Penerangan.

52 Mestika Zed, Sumatera Barat Di Panggung Sejarah 1945-1995 (Padang: Bidang Penerbitan Khusus Panitia Peringatan 50 Tahun RI Sumatera Barat, 1995), p. 20.

${ }_{53}$ Mestika Zed and Hasril Chaniago, Perlawanan Seorang Pejuang. Biografi Kolonel Ahmad Hussein (Jakarta: Sinar Harapan, 2001), p. 21

54 Zed and Chaniago. 
was recorded as one of the main initiators along with a number of regional elite who wandered about and had just returned to rebuild the country that was destroyed after the war ${ }^{55}$.

Brig. Gen. Surjo Soempono, in 1958 (the year when several important cities in Central Sumatara had been cleansed of rebels), gathered the "clean" Central Sumatra scholars into the Indonesian Bachelor Association (ISI) in Padang. The purpose of this association was clearly to help the central government calm down the upheavals of the rebellion; this association was expected to "play a role in contributing ideas to solve social problems, to reduce the rebellion, to create unity and integrity, in accordance with the goals expected by the Commander" ${ }^{56}$.

In Rahman, one of the elites who wandered about was a person named Azhari, who was then appointed by the Commander to be the ISI leader ${ }^{57}$. Under the leadership of Azhari, ISI began to think about the efforts to revive Islamic Collegesthat had been buried due to the rebellion. Azhari responded to the command of the military commander by encouraging ISI to form the Imam Bonjol Foundation, which was legally established on February 19, $1962^{58}$. The foundation was the forerunner of the IAIN Imam Bonjol Padang (now UIN), the first Islamic College after the uprising in Central Sumatra, which later spawned two other IAINs in the area: IAIN Bukittinggi and IAIN Batusangkar.

55 Yulizal Yunus, LAIN Imam Bonjol 30 Tabun (Padang: IAIN IB Press, 1996), p. 5.

56 Yulizal Yunus.

57 A Malik Rahman, 'Sekelumit Dari Sedjarah Berdirinja IAIN Sebagai Suatu Al Djami'ah "Imam Bondjol" Di Sumatra Barat"", in Brosur Menyambut Dies Natalis Ke-1 LAIN Al Djami'ah Imam Bondjol Sumatra Barat (Padang: Seksi Publikasi/Dokumentasi Panitia Dies Natalis ke-1 IAIN Al Djami'ah Imam Bondjol, 1967), p. 2.

58 Yulizal Yunus.

\section{Conclusion}

So far we have seen how the ideas about Islamic Colleges had grown among early Muslim scholars, then realized in the form of establishing Islamic College the local level of Central Sumatra, but then the political conditions had buried them quickly before they could develop. Then in the following period, the ideas were revived again, this time by a postwar condition controlled by the army-its mean, by the military of the winner of the war. These ideas were to bridge the competing and conflicting frictions (young people [Kaum Muda] and old people [Kaum Tua]) and also to bridge the elements that were still opposite to each other (Islamic and Western science)—with all the discourse and polemic that followed. All that is inherited by Islamic colleges in this area until now.

\section{References}

\section{Books}

Abaza, Mona, Islamic Education: Perceptions and Exchanges: Indonesian Students in Cairo (Paris: EHESS, 1994)

Azra, Azyumardi, 'IAIN di Tengah Paradigma Baru Perguruan Tinggi', in Problem \& Prospek LAIN: Antologi Pendidikan Tinggi Islam (Jakarta: Departemen Agama RI, 2003)

Dhofier, Zamakhsyari, 'Refleksi atas Visi dan Misi IAIN', in Problem \& Prospek IAIN: Antologi Pendidikan Tinggi Islam (Jakarta: Departemen Agama RI, 2002)

Djamin, Muhammad Dalir, 'Riwajat Ringkas Prof. H. Mahmud Junus', in Brosur Menyambut Dies Natalis Ke-1 IAIN Al Djamiah Imam Bondjol Sumatra Barat (Padang: Seksi Publikasi/Dokumentasi Panitia Dies Natalis ke-1 IAIN Al Djami'ah Imam Bondjol, 1967)

Garaghan, Gilbert J., A. Guide to Historical Method (New York: Fordham University Press, 1984)

Jabali, Fuad, and Jamhari, IAIN \& Modernisasi Islam di Indonesia (Jakarta: Logos Wacana 
Ilmu, 2003)

Kuntowijoyo, Metodologi Sejarah, Edisi Kedua, (Yogyakarta: Tiara Wacana Yogya, 2003)

Lukens-Bull, Ronald A., Islamic Higher Education in Indonesia: Continuity and Conflict (New York: Pargrave Macmillan, 2013) $<$ https://doi.org/10.1057/97811373134 $16>$

Meuleman, Johan Hendrik, 'IAIN di Persimpangan Jalan', in Problem \& Prospek. IAIN: Antologi Pendidikan Tinggi Islam (Jakarta: Departemen Agama RI, 2002), p. 23

Natsir, Muhammad, Capita Selecta (Bandung: Penerbit Bulan Bintang, 1973)

Rahman, A Malik, 'Sekelumit dari Sedjarah Berdirinja IAIN Sebagai suatu $\mathrm{Al}$ Djami'ah "Imam Bondjol" di Sumatra Barat", in Brosur Menyambut Dies Natalis Ke-1 IAIN Al Djami'ah Imam Bondjol Sumatra Barat (Padang: Seksi Publikasi/Dokumentasi Panitia Dies Natalis ke-1 IAIN Al Djami'ah Imam Bondjol, 1967), p. 2

Samry, Wannofri, and Yudhi Andoni, Demi Kejayaan Bangsa, Sejarah 50 Tabun Universitas Andalas (Padang: Unand Press, 2006)

Schroeder, Ralph, and Christopher Lloyd, The Structures of History., The Journal of the Royal Anthropological Institute (Blackwell Oxford, 1995), <https://doi.org/10.2307/3034263>

Tim Kementerian Penerangan, Sumatera Tengah Jakarta: Penerbit Kementerian Penerangan, 1953)

Yunus, Mahmud, Sedjarah Islam di Minangkabau: Keringkasan (Jakarta: AlHidajah, 1971)

— Sedjarah Pendidikan Islam di Indonesia (Jakarta: Hidakarya Agung, 1996) $<$ https://scholar.google.com/scholar?hl $=$ en\&q $=$ pendidikan + islam\&btnG $=\& a s$ $\mathrm{sdt}=1 \% 2 \mathrm{C} 5 \&$ as_sdtp $=\# 3>$

Yunus, Yulizal, IAIN Imam Bonjol 30 Tabun (Padang: IAIN IB Press, 1996)
Zed, Mestika, Sumatera Barat di Panggung Sejarah 1945-1995 (Padang: Bidang Penerbitan Khusus Panitia Peringatan 50 Tahun RI Sumatera Barat, 1995)

Zed, Mestika, and Hasril Chaniago, Perlawanan Seorang Pejuang. Biografi Kolonel Abmad Hussein (Jakarta: Sinar Harapan, 2001)

\section{Journals}

Feener, R. Michael, 'Indonesian Movements for the Creation of a "National Madhhab", Islamic Law and Society, 9 (2002), 83-115 <https://doi.org/10.1163/15685190275 3649298>

Ikhwan, Afiful, 'Perguruan Tinggi Islam dan Integrasi Keilmuan Islam: Sebuah Realitas Menghadapi Tantangan Masa Depan', Juran At-Tajdid, 5 (2016), 159-87

Indra, Hasbi, 'Pendidikan Tinggi Islam dan Peradaban Indonesia', Al-Tabrir: Jurnal Pemikiran Islam, 16 (2016), 109 $<$ https://doi.org/10.21154/altahrir.v16i1.317>

Minhaji, Akh., 'Masa Depan Perguruan Tinggi Islam di Indonesia; Perspektif SejarahSosial', Tadris Jurnal Pendidikan Islam Jurusan Tarbiyah STAIN Pamekasan, 2 (2007), 154

Nathan, Andrew J., and Andrew Scobell, 'How China Sees America', Foreign Affairs, $91 \quad$ (2012) <https://doi.org/10.1017/CBO9781107 415324.004>

Natsir, Muhammad, 'Sekolah Tinggi Islam', Pedoman Masjarakat, 6 (1938), 1-12

Roff, William R, 'Indonesian and Malay Students in Cairo in the 1920's', Indonesia, 1970, 73-87

Salahuddin, Marwan, 'Model Pengembangan Pendidikan Tinggi Islam di Indonesia', Ulumuna, 18 (2017), 121-38 $<$ https://doi.org/10.20414/ujis.v18i1.15 5>

Welch, Anthony, 'Seek Knowledge throughout the World? Mobility in Islamic Higher Education', Research in Comparative and 
International Education, 7 (2012), 70-80 <https://doi.org/10.2304/rcie.2012.7.1. $70>$

, 'Seek Knowledge throughout the World? Mobility in Islamic Higher Education', Research in Comparative and International Education, 2012 <https://doi.org/10.2304/rcie.2012.7.1. $70>$

Wirjosandjoyo, Satiman, 'Pendirian Sekolah Tinggi Islam', Pedoman Masjarakat, 6 (1938), 1-12

\section{Other references}

Hardianti, 'Pemikiran Politik Islam Soekiman Wirjosandjojo (1916-1960 M)' \{unpublish bachelor thesis, UIN Sunan Ampel, 2018\}

Kinoshita, Hiroko, 'Islamic Higher Education in Contemporary Indonesia: Through the Islamic Intellectuals of Al-Azharite Alumni', in Kyoto Working Paper on Area Studies, No. 79 Kyoto University, 2009<https:// repository.kulib.kyotou.ac.jp/dspace/bitstream/2433/155748/1 /ssh_081.pdf $>$. $\{$ accessed 7 December $2019\}$ 